\title{
A imprensa negra e o futebol em São Paulo no início do século XX
}

CDD. 20.ed. 796.05

796.33
Bruno Otávio de Lacerda ABRAHÃO*

Antonio J orge Gonçalves SOARES ${ }^{*}$
*Instituto Metodista Izabela Hendrix.

**Universidade Federal

do Rio de Janeiro.

\section{Resumo}

Em São Paulo, na primeira metade do século XX, havia associações destinadas à promoção de atividades culturais e esportivas para os negros, que surgiram diante da necessidade de denunciar as práticas discriminatórias e promover a sociabilidade étnica através do atletismo, do boxe e, sobretudo, do futebol. Uma delas era a Imprensa Negra. Neste artigo, os autores buscaram compreender as estratégias da Imprensa Negra para noticiar a participação do negro no emergente campo do futebol. Utilizando a perspectiva teórica da História Cultural, se ocuparam dos conteúdos das matérias dos jornais da Imprensa Negra, disponíveis na Biblioteca Nacional na forma de microfilmes. 0 objetivo foi observar a continuidade e a regularidade do discurso, os pontos de afrontamento e de disputa simbólica em torno da negociação da construção identitária da "raça negra" no esporte e captar, através das mensagens emitidas por esses órgãos da imprensa, as estratégias de distinção utilizadas por esse grupo étnico/racial em torno da contestação das representações negativas ou construção de representações positivas sobre o negro no emergente campo do futebol. Concluiram que o sentimento de consciência racial, a necessidade de se integrar à nação e o desejo de ascensão social eram os motivos que mantinham unidos os negros através daquelas associações. A Imprensa Negra procurou construir uma representação identitária do negro que privilegiasse o capital futebolístico, sem se esquecer dos predicados morais como a disciplina, a higiene e a ordem. A estratégia de divulgação dos feitos de sucesso dos negros no campo esportivo promovia uma identidade positiva do negro no futebol, em conformidade com as demandas daquele contexto: uma nação higienizada e disciplinada na esteira do projeto nacional que via no futebol um meio de expressão positiva da brasilidade.

UnIteRmos: São Paulo; Jornais; Imprensa Negra; Futebol.

\section{Introdução}

Em São Paulo, na primeira metade do século XX, havia associaçôes destinadas à promoção de atividades culturais e esportivas para negros ${ }^{1}$. Tais centros surgiram diante da necessidade de denunciar as práticas discriminatórias e promover a sociabilidade étnica/racial através de modalidades esportivas como o atletismo, o boxe e, principalmente, o futebol.

Esses espaços de convivência se configuraram meios de afirmação étnica/racial e locais de discussão sobre os embates sociais, políticos e culturais a respeito da participação do negro naquela sociedade pós-escravocrata e republicana. A partir de então, outro modo de integração passou a existir e a ganhar importância: a atitude passiva fora substituída por uma mobilização política e pelo cultivo da identidade racial (Giacomini, 2006).
A Imprensa Negra era uma dessas formas de mobilização. Domingues (2009) explica que libertos, no período pós-abolição, os ex-escravos e seus descendentes eram, geralmente, representados de forma negativa pelos jornais da grande imprensa. Os jornais surgiram justamente diante da demanda de abordar os problemas, eventos, feitos e sonhos para comunidade negra que, na "outra" imprensa, era praticamente inexistente. Foi nesse contexto de agitada imprensa alternativa que nasceram os jornais. produzidos por negros e voltados para luta em defesa de suas questōes: "tratava-se de uma rede de comunicação, expressão cultural, articulação de ideias e reivindicação política de um segmento sem voz ou visibilidade na sociedade brasileira" (Domingues, 2009, p.96). 
Em suas páginas as demandas desse grupo étni$\mathrm{co} /$ racial encontravam eco. Ao analisar os aspectos dos movimentos negros em São Paulo no período de 1915 a 1935, PIRES (2005) observou que essa imprensa foi um movimento que apresentou várias facetas ideológicas e esteve relacionada com os contextos econômicos, políticos, culturais e sociais daquele período, especialmente aqueles ligados à questão racial. Esse espaço de aglutinação representava não só o engajamento político dos negros, mas também a participação desse grupo nos assuntos relacionados ao poder e aos modelos de organização social em debate na sociedade, revelando, com efeito, aspectos relativos à questão do negro no Brasil.

Ainda que os jornais representassem mais as ideias da classe média negra, como professores, advogados e jornalistas, do que as do grande contingente de negros, BASTIDE (1973) argumenta que esses negros de classe média teriam fortes relações com as classes mais baixas e representariam as posturas ideológicas de alguns grupos de negros. Por isso, podemos tomar as vozes da Imprensa Negra como "eco de toda uma classe de cor" (BASTIDE, 1973, p.131), sobretudo no que diz respeito aos protestos antirracistas e reivindicaçōes materiais e de cidadania.

Era por meio daquelas "associaçôes de homens de cor" (PIRES, 2005, p.7) que os negros paulistas participavam ativamente das discussōes naquele período acerca dos embates ideológicos que transcorriam no âmbito nacional a respeito do negro. Refletindo uma tendência nacional, os defensores de uma democracia racial tornaramse hegemônicos no interior daquele campo. A documentação da Imprensa Negra sugere que diversos intelectuais e dirigentes das associações de homens de cor defendiam a ideologia da democracia racial não sob o ponto de vista dos diversos grupos de pessoas brancas - ou seja, baseada na mestiçagem biológica e cultural -, mas como um projeto social erguido em bases sólidas. Nessa perspectiva, o Brasil poderia se tornar um paraíso racial (PIRES, 2005).

ANDREws (1998) argumenta que os jornais da Imprensa Negra revelam os interesses e preocupações da elite negra de São Paulo na época e, por isso, constituem "um registro rico das preocupaçōes coletivas daquela elite negra" (p.201-2). Uma dessas preocupaçōes convergia para "um debate mais amplo sobre as fundaçôes ideológicas básicas da vida brasileira do século XX: o conceito de democracia racial" (p.203).

De acordo com ANDREWs (1998), a abolição não conseguiu satisfazer às necessidades culturais, religiosas e humanas dos negros. Isso abriu possibilidades para que eles se organizassem em condiçóes diferentes daquelas da escravidão. Reagindo às novas necessidades, os negros tiveram que experimentar diferentes possibilidades de associação. Se a Imprensa Negra foi uma dessas formas de organização, o futebol foi outra. Essa modalidade esportiva exprimia as expressōes culturais valorizadas pelos afro-brasileiros e era promovida pelas "associações dos homens de cor", que chegaram, inclusive, a organizar partidas entre times de brancos e pretos ${ }^{2}$. O desempenho dos times de pretos, que com frequência se sobrepunham aos brancos nesses jogos, reverberava nas páginas dos jornais da Imprensa Negra e servia para fortalecer as identidades negras naquele contexto (PIRES, 2005).

O futebol era um dos poucos espaços daquela sociedade recém-saída da escravidão em que o negro encontrava reconhecimento, visibilidade e prestígio. $\mathrm{Na}$ mesma direção, as páginas da Imprensa Negra eram um dos poucos espaços onde esse desempenho atlético-esportivo era noticiado, com o intuito de capitalizar a positivação da "raça negra" numa atmosfera cultural totalmente adversa, embebida de preconceitos e estereótipos ${ }^{3}$ contra esse grupo étnico/ racial. Diante disso, este artigo objetiva compreender as estratégias da Imprensa Negra para noticiar a participação do negro no emergente campo do futebol.

Antes, porém, é importante ressaltar que do ponto de vista da genética, "raça" é um conceito desprovido de qualquer valor científico. Logo, na área da pesquisa genética, não é possível fixar sistemas de classificação universal (D'ADESKY, 2005). No entanto, a desconstrução científica da raça biológica, continua D'ADESKY, não faz desaparecer a evidência da raça simbólica. Acima de tudo, o imaginário racista alimenta-se das semelhanças e das diferenças fenotípicas da cor da pele e das diversas características morfológicas. Portanto, se para a biologia a noção de raça coloca problemas insolúveis de definição que a torna ultrapassada, sua importância, indubitavelmente, não pode ser negada no plano simbólico. A "raça", querendo ou não, permanece sendo um elemento maior da realidade social, na medida em que emprega, a partir de características visíveis, formas coletivas de diferenciação classificatória e hierárquica que podem engendrar, às vezes, comportamentos discriminatórios individuais e coletivos (D'ADESKY, 2005).

Os estudos de Pena e Birchal (2005-2006) demonstraram que, no Brasil, a cor avaliada fenotipicamente tem pouca ou nenhuma relevância biológica. A ciência, assim, afasta o equívoco da noção biológica de raça e, consequentemente, qualquer fundamento do racismo. No entanto, apesar da demonstração das 
limitações do conceito biológico de raça e de sua desconstrução histórica, "o racismo persiste enquanto fenômeno social, mesmo não mais justificado por fundamentos biológicos" (SCHWARCZ, 2001, p.35-6).

Por essa perspectiva, "raça" deixou de ser uma realidade biológica para se tornar um artefato social, político e histórico. Ou seja, se por um lado a "raça" perdeu grande parte de sua credibilidade e deixou de ser oficial quando perdeu o estatuto científico, por outro lado, no plano das relaçôes culturais, econômicas e políticas, ela é facilmente identificada como um importante eixo norteador de diversos planos da vida cotidiana dos brasileiros. Internalizada na ditadura do senso comum, seus reflexos persistem no dia a dia de grupos e indivíduos e nas falácias do cotidiano (SCHWARCZ, 2001).

Evidentemente, para os seres humanos, a "raça" que existe é apenas uma: a humana. O que há são etnias ${ }^{4}$, e isso revela como, no Brasil, "raça" e "cor" são termos intercambiáveis. A raça humana é única e a espécie "Homo sapiens" é representada por grupos de características diversas, os fenótipos. A cor da pele, o formato da face, a grossura dos lábios e a textura do cabelo são traços ressignificados no plano cultural para vincular o pertencimento simbólico do indivíduo à "raça”. Uma vez selecionadas pelo fenótipo e inscritas no plano simbólico da cultura brasileira, as representaçōes sobre a "raça negra" rememoram a (ou se baseiam na) condição inferiorizada dos negros escravizados durante os períodos colonial e imperial da história do Brasil.

Este artigo dialoga com as representaçôes socialmente construídas sobre o negro no "campo" do futebol e deseja iluminar o processo de disputa construído em torno dessa representação, valendose, para tanto, da perspectiva metodológica da História Cultural (CHARTIER, 1990), que objetiva identificar "o modo como em diferentes lugares e momentos uma determinada realidade social é construída, pensada, dada a ler” (p.17).

\section{Método}

Ao analisar as publicações anteriores a 1940, ANDREWS (1998) se deparou com uma documentação de 20 jornais semanais e mensais "produzidos por e para aquela elite negra"5 (ANDREWs, 1998, p.202). Parte dela encontra-se microfilmada na Biblioteca Nacional, no Rio de Janeiro.

A fim de atender aos propósitos deste artigo, utilizamos como fonte os escritos da "Imprensa Negra". Os jornais pesquisados e que tiveram seus conteúdos analisados foram aqueles disponibilizados pela Biblioteca Nacional no formato de microfilmes. São eles: $A$ Voz da Raça, de circulação nacional, referente a março de 1933; O Clarim da Alvorada, referente a janeiro de 1924; O Kosmos, referente a agosto de 1922; O Alviverde, de abril de 1928; O Progresso, também de circulação nacional, de junho de 1928; O Baluarte, de janeiro de 1904; O Menelik, de outubro de 1915; A Rua, de fevereiro de 1916; OXanter, de maio de 1916; O Alfinete, de setembro de 1918; A Liberdade, de julho de 1919; A Sentinela, de outubro de 1920; Getulino, de agosto de 1923; A Elite, de janeiro de 1924; e, finalmente, O Patrocinio, referente a abril de 1928.

Basicamente, foram selecionadas matérias de dois jornais: O Progresso, de junho de 1928 até o dia 15 de novembro de 1931, quando, ao que tudo indica, saiu de circulação; e $A$ Voz da Raça, um semanário que teve sua primeira publicação em 18 de março de 1933 e trazia uma frase de Isaltino Veiga, reproduzida em todas as edições: "o preconceito de cor no Brasil só os negros podem sentir...”. Esses jornais tinham periodicidade quinzenal ou mensal, não tiveram uma vida longa e nem todos tratavam do esporte. Selecionamos aquelas matérias dos jornais da Imprensa Negra que se ocuparam do esporte.

As páginas da Imprensa Negra traziam as escolhas de identificação daquele grupo étnico em meio à proliferação de estereótipos positivos e negativos a respeito dos negros. Sendo assim, tomaremos as páginas da Imprensa Negra não apenas como um meio de contestação daqueles estereótipos negativos, mas também como um espaço de agenciamento dos estereótipos positivos que atribuíam aos negros uma suposta superioridade no campo do futebol, numa sociedade em que esse esporte começava a ganhar importância.

Adotamos neste artigo uma concepção dinâmica da identidade proposta por BARTH (1998) para leitura das fontes. $\mathrm{O}$ autor mostra que a identidade étnica, assim como qualquer outra identidade coletiva, é construída na interação de grupos sociais, através de processos de exclusão e inclusão que estabelecem limites para tais grupos, definindo os que os integram ou não. Logo, o que importa é procurar saber em que consistem tais processos de organização social por meio dos quais se mantêm de forma duradoura as 
distinçôes entre "nós" e "os outros", mesmo quando mudam as diferenças que, para nós, assim como para "os outros", justificam e legitimam tais distinçōes. Pois em tais processos, escreve BARTH, as características que são levadas em consideração não são a soma das características objetivas, mas somente aquelas que os próprios atores consideram significantes. [...] alguns traços culturais são utilizados pelos atores como sinais e emblemas de diferenças, outros são ignorados, e, em alguns relacionamentos, diferenças radicais são minimizadas e negadas (BARTH, 1998, p.194).

BARTH (1998) assinala que os "traços culturais diferenciadores" riscam a linha de demarcação entre os grupos étnicos e podem variar no decorrer do tempo e ao sabor das interações com outros grupos. Esses "traços culturais diferenciadores" não são uma coisa qualquer, eles se formaram no curso de uma história comum que a memória coletiva do grupo nunca deixou de transmitir de modo seletivo e interpretar, transformando determinados fatos e determinados personagens lendários, por meio de um trabalho do imaginário social, em símbolos significativos de identidade étnica (Lapierre, 1988, p.12).

A partir da perspectiva de CHARTIER (1990), o mundo seria resultado das representaçôes que o instituem como tal. Este mundo que CHARTIER vislumbra é, na verdade, uma arena de representaçóes que estão em concorrência e competição. A História, nesse sentido, seria o estudo dos processos pelos quais se constrói um sentido, na medida em que ela se dirige para as práticas discursivas, produtoras de ordenamentos, afirmação de distâncias, divisões que dão significado ao mundo, e objetiva "compreender as práticas, complexas, múltiplas, diferenciadas, que constroem o mundo como representação" (CHARTIER, 1990, p.28).

CHARTIER (1990) nos ajuda a compreender o processo de disputa em torno da construção das representações sobre o negro no futebol quando nos diz que as representações não são neutras ${ }^{6}$; ao contrário, são determinadas pelos interesses e pela afirmação de valores dos grupos dominantes ou dos que as forjam: "Daí, para cada caso, o necessário relacionamento dos discursos proferidos com a posição de quem os utiliza” (p.17).

Em particular nos preocupamos em analisar os pontos de afrontamento e de disputa simbólica em torno da construção da identidade negra. Para tanto, deve-se considerar

os esquemas geradores de classificação e das percepçôes, próprios de cada grupo ou meio, como verdadeiras instituiçōes sociais, incorporando sobre a forma de categorias mentais e representações coletivas as demarcações da própria organização social (CHARTIER, 1990, p.18).

Isso nos induz a considerar as representações como "as matrizes de discursos e de práticas diferenciadas [...] que têm por objetivo a construção do mundo social, e como tal a definição contraditória das identidades - tanto a dos outros como a sua" (CHARTIER, 1990). Isso leva a crer que as práticas discursivas são produtoras de ordenamento e de formas diferenciadas de interpretação.

Sendo assim, foi necessário nos aproximarmos de uma das perspectivas teóricas da etnicidade, chamada de "grupo de interesse", que postula que as identidades e as ideologias étnicas são mantidas e enfatizadas para exercer uma influência nas políticas sociais e econômicas. A etnicidade é vista como uma solidariedade do grupo emergente em situaçôes conflituais entre indivíduos que possuem interesses materiais em comum (Poutignat \& Streiff-Fenart, 1998, p.96).

Essa teoria tem como foco o processo de competição em torno da construção das representações: "esta abordagem compreende, contudo, muitas variantes nas quais a ênfase é colocada ora nos fins e nas estratégias individuais, ora nas lutas de poder coletivas" (Poutignat \& Streiff-Fenart, 1998). Diante disso, a questão fundamental seria

compreender as condiçóes nas quais os indivíduos que podem reclamar uma pertença étnica são levados a desenvolver uma solidariedade com outros indivíduos pertencentes à mesma categoria para conseguir vantagens políticas ou econômicas (Poutignat \& Streiff-Fenart, 1998, p.96).

A etnicidade (entendida aqui como uma forma de organização social numa base étnica) propicia uma alternativa coletiva que permite o desenvolvimento de estratégias de sucesso econômico e promoção do grupo. Nesse caso temos que encarar o realce de uma identidade étnica como uma construção dos múltiplos estereótipos pelos quais determinados membros de uma sociedade pluralista definem pessoas e situações. Nela os indivíduos conhecem a existência e o conteúdo dos estereótipos construídos pelos "estabelecidos" (Elias \& SCOTSOn, 2000).

As mensagens emitidas por esses órgãos da imprensa podem ser lidas como produtoras de ordenamentos que revelam as estratégias de distinção utilizadas por essegrupo étnico/racial em torno da contestação das representaçôes negativas ou da construção de representações positivas sobre o negro no emergente campo do futebol. Tentaremos captar, através das matérias publicadas nas primeiras 
décadas do século $\mathrm{XX}$, a continuidade e a regularidade do discurso, e os pontos de afrontamento e de disputa simbólica em torno da negociação da construção identitária da "raça negra" no esporte.

\section{O surgimento da Associação Athlética São Geraldo: a Imprensa Negra e o negro no esporte}

A noção de campo, definida na obra de BourDIEU (1989), serve como guia de leitura, uma vez que ela atribui especial importância à dimensão simbólica ou cultural na reprodução das estruturas de dominação social, definindo-se em função do modo como se distribuem, em dada sociedade, diferentes formas de poder, ou seja, "diferentes tipos de capital". Um desses tipos seria o capital futebolístico (DAMO, 2007).

O conceito de capital futebolístico, como modalidade específica de capital exigida daqueles que pretendem fazer parte do "campo do futebol", foi concebido a partir da influência de Bourdieu "como uma constelação de atributos que permitem a alguém se inserir legitimamente num dado campo social" (DАмо, 2007, p.112). Em sentido restrito, referindo-se aos atributos propriamente corporais de um indivíduo,

os capitais futebolísticos perfazem um leque amplo e variado de disposiçôes físicas, psíquicas e sociais que extrapolam, significativamente, a dimensão técnica e, sobretudo, uma dada dimensão em particular, muito valorizada pelo senso comum, associada ao controle da bola malabarismos, floreios, etc. (DAMO, 2007, p.112).

Essa estratégia, em última instância, favoreceria o acesso do negro num espaço em que era até então preterido, como veremos à frente. Um dos debates naquele contexto era a participação dos negros na transição do amadorismo para o profissionalismo ${ }^{7}$ no futebol. Atividade do âmbito do lazer anteriormente idealizada pela e para a elite, o futebol apresentava nas primeiras décadas do século XX indícios de profissionalização ${ }^{8}$. Nesse contexto, o desempenho positivo do jogador negro começava a ser reconhecido nos campos de várzea ou nos bairros populares. Tal desempenho poderia ser convertido em favor das equipes de clubes elitistas, mas muitos desses jogadores não eram incorporados por elas. Estaríamos diante do preconceito à brasileira, que dificultava o acesso dos populares aos espaços reservados às elites?

A incorporação dos populares em um espaço idealizado para a elite era um dos temas em discussão naquele período em que o futebol deixava de ser visto como lazer e passava a ser encarado como trabalho. Tomaz Mazzoni (1950), por exemplo, aponta que em 1918 esta discussão apareceu nos jornais: "Afinal de contas em que pé estamos? Jogadores de cor podem ou não podem jogar nos campos oficiais?" (p.120), era o que perguntavam os cronistas esportivos da época. O futebol caminhava rumo à profissionalização e nesse espaço o negro encontrava a expressão positiva de sua identidade e a oportunidade de ascensão social em tempos de mobilidade mais restrita.

Respirando os ares da profissionalização, o futebol começava a se configurar num meio de oportunidades e de mobilidade econômica e social. Isso fazia com que os capitais futebolísticos identificados nos negros pudessem ser convertidos em favor daqueles que vislumbravam, através do futebol, um espaço e um meio de mobilidade (Rosenfeld, 1993). O futebol possibilitava ao "elemento de cor um futuro garantido, que, sem o futebol, lhes teria permanecido inatingível" (Rosenfeld, 1993, p.92). Além disso, as possibilidades econômicas não se restringiam naturalmente só aos vencimentos e adicionais; "referem-se, em alto grau, também ao prestígio pessoal que o jogador adquire em amplos círculos e que lhe assegura em numerosos casos rendimentos do tipo mais ou boas colocações" (Rosenfeld, 1993, p.94). O futebol, que começava a ser promovido pelos clubes sociais, se apresentava como um espaço de mobilidade econômico-social, bem como um meio de ampliação de capital social.

ANDREWs (1998) cita os clubes mais conhecidos: a Associação Athlética São Geraldo, criada em torno de 1910, e o Clube Cravos Vermelhos, fundado em 1916, que mais tarde transformou-se em Clube Athlético Brasil. Ocuparemo-nos do primeiro. O São Geraldo era um dos clubes mais citados pela Imprensa Negra, que noticiava suas vitórias nos campos de futebol. Seus feitos exitosos vinham acompanhados de adjetivos positivos sobre a participação do negro no esporte, especialmente o futebol.

Passamos a conhecer o São Geraldo pelo fato das fontes noticiarem, com recorrência, seus feitos exitosos nas partidas e campeonatos de que participava. No próximo trecho observaremos as demandas 
relativas ao surgimento deste clube, destinado à promoção do futebol para os pretos.

O São Geraldo é um clube que honra a colletividade negra no futebol paulista.

Por tal fez jus o proseguimento desta campanha em prol da valorosa equipe Barrafundiana, para representar officialmente, o esporte da raça [...]. Contudo, damos o pensamento do sr. Alcides Hortencio, futebolísta da A. A. Palmares, que falou-nos em entrevista:

- é de necessidade que haja nessa capital, como em outros estados do paiz, entidades de esportistas negros, onde os seus associados, athletas e futebolístas, possam aperfeiçoar suas culturas físicas sem receiar preconceitos como há em muitas agremiaçōes esportivas, que não os acceitam como socios, mas só como athletas, isto é, quando são bons elementos que possam elevar o clube. $\mathrm{E}$ assim numa associação de esportistas negros, podemos nos desenvolver no futebol e no atletismo, mesmo fazer carreira sem medir dificuldades. Mas para isso urge se fazer uma entidade digna da confiança de todos os deveres de cooperação para manter o seu clube.

Dahi então estará realisada em nossa capital, uma das aspiraçóes da raça negra, e muitos outros patrícios de outros lugares hão de imitar.

(O Clarim da Alvorada, 26/07/1931, p.3).

"Aperfeiçoar suas culturas físicas": esta era uma das demandas daquela entidade de negros. $\mathrm{O}$ texto da matéria revela que o São Geraldo era uma instituição que objetivava "oficialmente" divulgar a imagem da raça negra através do esporte. Treinando, futebol ou atletismo poderiam ser convertidos em profissão. Suas instalações permitiam aos negros, em tempos de preconceitos mais explícitos, sentir-se à vontade e exercitarse para o "aprimoramento" da raça. Através do futebol e do atletismo, os negros encontrariam no São Geraldo um bom espaço para emancipação econômica e para aquisição de capital social. Por isso, a iniciativa deste clube deveria servir de inspiração para o surgimento de novos clubes com esse perfil, a fim de se combater a discriminação contra os pretos no campo do futebol.

No próximo texto, assinado por Adalberto Pires Freitas, em 1930, aparece uma denúncia de discriminação racial, que operava contra o negro no espaço do esporte naquele início de século XX. Eis um ingrediente a mais para ser adicionado ao surgimento deste clube na capital paulista: um espaço de combate à discriminação contra os pretos.

Para orgulho dos pretos

Agora, que o Progresso largou a idéia, em via de conclusão, de se homenagear Luis Gama, trazemos á apreciação dos interessados uma suggestão que na realidade é de grande interesse. Trata-se da Confederação Esportiva dos Homens Pretos do Brasil.

Nela teria ingresso essa infinidade de esportistas que andam vegetando nos diversos clubes; nos quais aparecem somente durante as provas esportivas; mas são alijados das festas comemorativas da victoria, da qual muitas vêzes foram elles os fatores primordiaes. Nos clubes do remo a preterição do negro é acentuada.

Negam-lhe tudo.

Vedam- lhe todos os direitos.

- Por que negro remador, ou nadador?

Contente-se em ser a semente da riqueza e do sofrimento do Brasil.

É o bastante.

Por essas e outras, é que aventamos a idéia da confederaçăo para termos nossa praça de esportes onde mostraremos com galhardia o valor do pulso negro, que humildemente, no passado, cingiu-se de algemas, e hoje, ufano, conduzirá á victoria qualquer esquadra esportiva, dentro da ordem para o progresso do Brasil. (O Progresso, 15/02/1930, p.5).

A Confederação Esportiva dos Homens Pretos do Brasil surgiu diante da necessidade de um jornal inclinado à causa negra, que denunciasse os obstáculos que os negros estavam enfrentando para ascender no campo esportivo. A interpretação do jornal negro reforça a tese do preconceito de marca, de Oracy Nogueira (1998), que sugere a especificidade do "racismo à brasileira". O preconceito à brasileira, diz Nogueira, ocorreria por preterição, traço discriminatório denunciado pelo jornal negro, que incidia sobre os negros que pleiteavam participar de esportes elitistas, a saber: o remo e a natação.

Nesse sentido, os dramas vividos pelos negros que pleiteavam ascender no campo esportivo se afinam com as conclusões de NogueIra (1998), que indica o verbo adequado para a compreensão das relações raciais na cultura brasileira: "preterir". É essa forma específica de rejeição que nos ajuda a entender as estratégias de resistência elaboradas pelas elites contra a popularização daquelas atividades esportivas que as identificavam.

Observe que a literatura denuncia uma forma de exclusão contra os negros no Brasil, mas não explica a maneira como ela operava. Apenas diz que o preconceito incidia sobre caracteres sociais. A literatura denuncia o preconceito à brasileira como um dos obstáculos encontrados pelos negros nos clubes. Não há indícios de discriminação explícita, mas sim de 
discriminação silenciosa, travestida por marcadores sociais. Divulgar essa forma de discriminação era uma das demandas da Imprensa Negra.

Esses periódicos não se limitavam a denunciar o "racismo à brasileira"; eles também divulgavam os feitos dos negros. A conquista da Copa do Centenário da Independência do Brasil rendeu ao São Geraldo um notável respeito na cidade. Há uma abundância de referências ao título de "Campeão do Centenário". A conquista desse título foi motivo de orgulho para aqueles que simpatizavam com o clube, e isso o tornava distintivo para aquele grupo étnico.

Em 1922, a Liga de Amadores de Futebol (LAF) deliberou que o campeonato daquele ano seria destinado à comemoração do centenário da independência do Brasil. A despeito do excessivo número de menções a esse título, não encontramos maiores informações que pudessem nos esclarecer como foi essa celebração, à exceção do livro de STORTI e FONTENELLE (1997), que diz sobre o ano do centenário:

Corinthians

Campeão do Centenário

Todos os participantes sabiam que aquela seria uma conquista diferente, já que o país estava mobilizado para comemorar o primeiro centenário da Independência, e o campeão ficaria marcado (StORTi \& Fontenelle, 1997, s.p).

Ainda que o texto se refira ao Corinthians, campeão da divisão principal, e o São Geraldo tenha vencido na divisão intermediária, podemos entrever os significados dessa competição prestigiosa e, segundo os autores, "diferente". Vencê-la seria uma forma de ser lembrado, como veremos abaixo no jornal O Progresso, da Imprensa Negra.

Campeão do Centenário

A Associação Athletica São Geraldo, é no violento esporte bretão, uma das agremiações mais respeitadas de São Paulo.

Não só seus quadros principaes como secundários, têm se empenhado jogos de valor, cuja victoria lhes seria difícil, si os onze que possuem na sua vanguarda a agilidade técnica de Dictinho não fossem mestres na sua posição. De há muito que o "S. Geraldo" se impôz nos meios esportivos de Piratininga. Os seus embates, em tempos no Pacaembu (fim da rua Tupy), marcaram tardes que acordam recordaçōes que os annos não conseguiram fazer esquecer.

Dali pra cá, os annaes esportivos vivem cheios, não só da disciplina, com a qual se caracteriza a associação da rua Victoriano Carmillo, como com as derrotas que o $S$. Geraldo, infligem nos seus denodados antagonistas.
Na história das festas, com que se comemorou, esportivamente, os 100 anos de vossa emancipação política, o clube que bem representa os pretos da capital e do estado de S. Paulo, occupa capitulo a parte. De um modo que os honra sobremaneira, o S. Geraldo conquistou a disputa do titulo de Campeão do Centenário. Deus, parece que escolheu a camiseta alvi-negra, para dar-lhes essa honrosa designação, evidenciando deste modo o quanto os pretos do Brasil devem a sua Independência.

Agora o "S. Geraldo", ocupa a vanguarda do Campeonato da Primeira Intermediaria da LAF (O Progresso, 28/07/1929, p.5, “Esporte”).

De luta em luta, o São Geraldo, é uma das agremiações de homens pretos, que, no esporte, tem sabido, não só na capital como, em todo Estado, honrar sobremaneira o nome do negro. Não é de hoje que o " 11 " da barra funda compreendeu seu papel no mundo esportivo.

De longa data vem o "S. Geraldo" apurando a sua performance.

Em 1922, honrosa e merecidamente levantou o título de Campeão do Centenário, denominação essa que os camisas alvi-negras souberam guardar com usura. Prova essa asserção o bello feito actual que veio collocar mais uma vês o S. Geraldo na dianteira de seus congêneres. (O Progresso, 26/09/1929, p.7).

Ano após ano, a partida final e a conquista daquele torneio eram rememoradas pelo jornal $A \mathrm{Voz} d a$ Raça. A seção "Gentes e fatos de outras épocas" era uma das partes do jornal destinada à divulgação de feitos gloriosos de instituições ou pessoas próximas ao jornal. O dia da final desse torneio distintivo foi rememorado pelo periódico.

Gentes e fatos de outras épocas - S. Geraldo Vs. Flor de Belém

O Flor de Belém F.C. foi o campeão municipal de 1923, cujo titulo no ano de 1922, dividiu-lhe a fé, pois a valorosa equipe da A. A. S. Geraldo ousou lograr-lhe, levando para a sua tenda o ambicionado título de campeão.

Com que saudades me lembro daquele bem fadado dia, em que dois contendores disputavam um titulo de honra...

O S. Geraldo, clube constituído, somente, de elementos de cor, contra a Flôr, formado por brancos. Eram nove horas do dia de domingo de Ressurreição de 1923, - dia da revisão do campeonato de futebol do Centenário - quando me encontrei 
com alguns dos elementos sãogeraldenses que demandavam as suas casas, a fim de descansarem, pois, na véspera, sábado de aleluia tinham passado a noite em claro. Eu, naquele tempo, era um dos membros da diretoria daquele clube; irritei-me, fiz-lhes ver a grande responsabilidade que iriam assumir dali a algumas horas.

Em cada rosto, em cada fisionomia, notava-se um ar de esperança, pois, o desanimo, não tinha siquer um sorriso da parte dos componentes do quadro que ia ganhar o campeonato.

E assim foi que no jogo, os jovens pretos, cançados, em conseqüência da noite perdida, anteriormente, produziam pouco, ou quasi nada, no primeiro tempo. $\mathrm{O}$ adversário entrava com dois pontos e os seus torcedores já o aclamavam campeão, mas como diz o provérbio: ri melhor quem rir por ultimo... Pois assim, no segundo tempo, diante da formidável pressão dos negros, o Flôr, tivera de ceder, indiscutivelmente, os pontos conquistados e mais um.

Oh!... Meu Deus! Que alegria, quando descrevo estas linhas!... sinto, em mim tamanha emoção... parece-me que estou ouvindo os gritos de entra!... centra...! não durma....! é sua!... e depois aquela vozeria que se elevara, demoradamente nos ares: gooool! Goool! E em triunfo, "os onze" saírem carregados do campo, levando para o $S$. Geraldo o ceptro de Campeáo Municipal do Centenário (A Voz dA RAÇA, 28/04/1934, s.p).

$\mathrm{O}$ trecho acima rememora, com uma boa dose de emoção, a vitória do São Geraldo sobre o Flor, que lhe rendeu o distintivo título de Campeão do Centenário. Mas quais são os significados da rememoração, por parte da Imprensa Negra, de uma competição idealizada para festejar o centenário da independência de uma nação cuja história estava marcada pela condição subserviente dos negros e que, ainda há pouco, vivia o fim da escravidão?

O destaque dado à vitória do São Geraldo objetivava ilustrar a potencialidade daqueles que, 50 anos antes, eram considerados os "párias" da sociedade brasileira. Em um jogo comemorativo do centenário da emancipação política de uma nação que os relegou a uma condição subserviente, a vitória do time dos pretos foi sentida como uma resposta dos afro-brasileiros aos outros membros daquela sociedade pós-escravocrata. As adversidades da partida foram dotadas de sentido simbólico para ilustrar, em resposta àquela sociedade liberal e preconceituosa, todo o valor da "raça negra".

A mensagem simbólica da vitória é a de que os negros souberam superar as adversidades do jogo, assim como souberam superar as adversidades que a história impôs àquele grupo étnico/racial. A vitória dos negros do São Geraldo foi sentida como afirmação dos valores identitários de um grupo que reivindicava reconhecimento e aceitação. Este era o alcance objetivado pelo discurso da Imprensa Negra, na qualidade de um movimento que tinha por missão enaltecer e reivindicar reconhecimento e integração daquele grupo étnico.

Dos predicados que poderiam ser elencados pela Imprensa Negra para favorecer o acesso do negro ao futebol, quais, em que situação e em que contexto foram utilizados por ela para se referir aos negros? Esse processo de adjetivação e construção de representações positivas pela Imprensa Negra transpassa a trajetória do São Geraldo, ganhando mais fôlego após o seu distintivo título.

Campeão do Centenário 1922

São Geraldo x Colombo

Conforme noticiamos, iniciou-se domingo o campeonato lafeano, sendo contendores da primeira divisão série intermediária, a A. A. Colombo e a A. A. São Geraldo.

O Colombo não deu pra sahida, pois a negrada sapecou-o só por 5 a 0. (O Auriverde, 15/04/1928, p.5).

O jornal, repleto de termos nativos, traduz parte dessa positividade. "Não dar para a saída" é uma expressão que denota um desequilíbrio de forças entre os oponentes; o termo "negrada", acionado naquele contexto e por seus "próximos", se reveste de um sentido carinhoso; "sapecar" é o mesmo que “surrar"; e, por fim, “só por 5 a 0 ” é um sarcasmo que serve para expressar a superioridade dos pretos que atuavam no São Geraldo em detrimento dos demais jogadores de quaisquer etnias.

São Geraldo x Brasil

Em continuação do Campeonato Lafeano, primeira divisão série intermediário, encontraramse domingo passado na Floresta, os primeiros e segundos quadros dos clubes acima, ambos formados por elementos de cor. Como se vê, dois bicudos.

- Primeiro quadro

São Geraldo, 3, Brasil, 0.

- Segundo quadro

São Geraldo 3, Brasil 1.

Assistencia numerosa, correcta, disciplinada, notando-se presente um bom número do sexo bello (O Auriverde, 29/04/1928, p.3).

O São Geraldo e o C. A. Brasil podem ser considerados os dois principais clubes de elementos 
de cor, uma vez que, segundo o jornal, seriam dois "bicudos". O desempenho desses clubes possibilitou transformá-los em modelos para clubes emergentes, mas com o mesmo perfil.

\section{Clube A. Brasil}

O C. Athlético Brasil, que vem tomando papel saliente nas pugas esportivas de S. Paulo, no presente campeonato da LAF, está fazendo sucesso. No mesmo jornal foi divulgado o surgimento do 'Esporte Clube Onze Gallos Pretos'.

Dado ao valor dos componentes do nosso clube, como o esforço da comissão fundadora, prevê desde a firme actuação dos gallos, que certamente tomarão por modelo, seus irmãos S. Geraldo e C. A. Brasil, formando assim nos meios esportivos uma tríade de respeito.

O Progresso, que foi proclamado órgão oficial do clube, deseja muitas victorias ao Gallo Preto (O Progresso, 28/07/1929, p.3).

É reincidente na Imprensa Negra um discurso que objetiva mostrar a positividade do negro no espaço do futebol, como podemos confirmar abaixo:

\section{A. A. S. Geraldo}

Este veterano dos filiados á extinta L.A.F. fechou o campeonato de 1929, de um modo brilhante e digno de todos os encontros.

Terminando o campeonato da $1^{\text {a }}$ divisão intermediaria, o São Geraldo suspendeu brilhantemente, o titulo de campeão de 1929, e foi um dos mais fortes concorrentes desse torneio; sustentando com galhardia o decorrer do anno, sem uma derrota para o seu quadro; os jogadores não soffreram a menor pena ou censura, em se tratando de disciplina. E isto para nós, é motivo de jubilo, pois, o S. Geraldo, é uma associação essencialmente de nossa classe; entre todos os jogos, apenas uma meta vazou o goal S. Geraldense; no mais, tudo foi levado de vencida, portanto, esse campeonato foi um anno de orgulho para os esportistas negros desta capital, e, a diretoria que conduziu o invicto S. Geraldo, no ano findo, está de parabéns, pela conquista deste alto troféu que irá enriquecer a sede deste nosso acatado grêmio esportivo. (O Clarim da Alvorada, 25/01/1930, p.2).

Disciplina e capacidade técnica foram os traços distintivos utilizados por este jornal para diferenciar um dos times que representavam os pretos da cidade de São Paulo. Estas representações foram utilizadas em um outro artigo jornalístico, assinado por Africano:

Tudo Preto

$\mathrm{Na}$ várzea, quando surge em campo qualquer jogador preto, a torcida brada logo

\begin{abstract}
- Ahi, bichão!
O ser preto é índice seguro de "altas qualidades" no manejo da bola de couro. Nos arrabaldes, pelo menos, o futebolista negro é olhado sempre com respeito e sympathia. [...]

O característico das agremiações negras é a disciplina. Haja vista os conjunctos que jogam por ai a fora. Entusiasmo transbordante sob uma alma ternamente compassiva, incapaz de quebrar pernas ou de "dar trabalho á policia" (O Progresso, fev. 1931, p.4).
\end{abstract}

Naquele período, o "ser negro" construído pelo branco incluía estereótipos de tipos desordeiros e violentos (ScHWARCZ, 2001). A matéria contesta esses estereótipos e exalta valores como a disciplina, a contenção da violência física, o respeito e a ordem. Diante da abundância de elogios ao desempenho dos pretos durante as partidas de futebol, podemos interpretar que as partidas dos times dos pretos transcorriam dentro da ordem e da disciplina, em uma palavra, civilizadas.

Isso servia tanto para contestar os estereótipos presentes naquela sociedade sobre as pessoas "de cor" quanto para reforçar outro estereótipo aparentemente positivo, a saber: a vocação quase inata do negro para o futebol. Nesse caso, a Imprensa Negra se posicionava na contramão dos estereótipos, mas mantinha uma relação ambígua em relação a eles. Isto é, buscava contestar e contrapor aqueles que comprometiam a identidade negra, mas, por outro lado, reforçava os estereótipos positivos sobre os negros, já que eles, segundo a matéria, seriam detentores de "altas qualidades" no manejo com a bola.

A disciplina parecia ser um valor que a Imprensa Negra queria afirmar para seus pares. $\mathrm{Na}$ mesma direção de afirmação de valores, DOMINGUEs (2009) reforça que as matérias publicadas por esses jornais buscavam construir uma imagem que o negro deveria ser trabalhador, honesto e cumpridor de seus deveres, além de selar pela moral e pelos bons costumes.

Todo esse ideário se refletia no esporte. Observe a matéria que divulgava um jogo do clube Frentenegrino, um clube negro. Na seção de esportes do jornal $A$ Voz da Raça lê-se:

a peleja esteve deveras movimentada e o jogo deveras equilibrado e interessante; ambos os quadros são dignos de uma menção; pois que os seus jogadores demonstraram no desenvolver do jogo, onde notamos disciplina, predicado que mais necessita um jogador (A VOZ DA RAÇA, 19/04/1933, p.4).

Outra questão levantada pela Imprensa Negra era a divulgação do esporte como um meio de aperfeiçoamento 
da raça. Lembremos que as teorias raciais apontavam os negros como seres degenerados física e moralmente (SCHWARCZ, 2002). Em tese, podemos arriscar que essas conclusōes "científicas" contaminavam os valores daquela sociedade pós-escravocrata.

O esporte, por sua vez, poderia ser um meio de contestação daquelas representações estereotipadas e de adequar os negros à ordem daquele contexto, qual seja: uma nação higienizada e disciplinada através do futebol, em conformidade com a ordem higienista vigente, como sugere o jornal $A$ Voz da Raça.

Página Esportiva

Praticar o esporte em todas as suas modalidades é um meio de se aperfeiçoar fisicamente a Raça. Atualmente, em todos os países, o esporte é encarado com carinho pelos jovens, interessados na maior robustês e energia de seus povos.

No Brasil, segundo os atos que já vão bem encaminhados, os jovens vão intervir na unificação e oficialização dos esportes, o que é uma necessidade premente, dado o dissidio que lavra no mundo esportivo brasileiro.

Também os clubes arrabaldinos ou varzeanos, devem ser filiados a uma entidade que os unifique e auxilie, dando-lhes mais vida, mais futebol, formado e composto por mais pujança, mais desenvolvimento.

É grande o numero de clubes de elementos negros, e que vivem, pululam e brilham por esta paulicéa afóra.

Clube Negro de Cultura, A. Atlética S. Geraldo, Brasil, Marujos Paulistas, Vitoria Paulista, C. E Flor da Penha e tantos outros são clubes futebolísticos, possuidores de verdadeiros atletas e malabaristas do esporte que consagrou Friedenreich. Através da justa fama que já gosa, chegou ao nosso conhecimento a existência de uma exemplar agremiação esportiva, composta de rapazes negros ordeiros e disciplinados, verdadeiros cavalheiros, tanto no campo, como fóra dele. (A Voz DA RAÇA, abr.1937, p.2).

A positivação do negro pela Imprensa Negra não ocorreu apenas nas páginas dos jornais, mas também nas revistas que começavam a surgir em meados do século XX. Tal positivação foi expressa em termos quantitativos quando, por exemplo, a revista Senzala apresentou um "censo" da constituição étnica dos jogadores brasileiros que se preparavam para disputar a Copa de 1950 no Brasil.

uma das causas que vem derrubar o velho tabu da inferioridade do negro em face a seu irmão branco, reside, indubitavelmente, no panorama desportivo da atualidade. O negro é detentor, nos desportos de sua preferência, de todos os postos máximos do conhecido atlético universal. Contudo, não é nossa intenção focalizar, no momento, as formidáveis atuações do "sprinter" Owen no atletismo e dos boxers Jonhson e Joe Lewis. Não. Queremos, tão somente, analisar, de um modo ligeiro, as "performances" do negro brasileiro no futebol. São pequenas notas, simples, concisas, claras, que abordarão apenas os futebolistas atuais, deixando para outra oportunidade, as figuras impressionantes de um Fried, um Fausto e um Patronilho.

Para não nos alongarmos muito, usamos, por exemplo, o atual selecionado nacional disputante do sul americano Extra, em Buenos Aires. [...] Portanto, de acordo com os quadros grifados, temos oito negros no quadro titular, 3 no quadro reserva e quatro entre os dispensados. Em resumo, dos 31 "players" dispensados por Flávio Costa, catorze são negros, o que nos dá u'a média de quase cinquenta por cento, isso sem falar do "onze titular" formado por sete negros e 4 brancos, fato esse que confere aos nossos, a formidável vantagem de setenta e cinco por cento.

Lembremos agora outras "estrelas" de primeira grandesa que actuam destacadamente nos grandes clubes de São Paulo e Rio [cita vários jogadores] e teremos uma conclusão que, se o negro destacou-se, sobremaneira no futebol, (o atletismo, na modalidade de corridas de fundo, e o Box, já vêm sendo tomados de assalto pelos nossos, que apresentam sempre atuações impressionantes) é devido, não só ao espírito democrático que campeia nos esportes atléticos em geral, como pela indiscutível fibra de lutadores filhos de Zumbi, o que desmentir 'in totum', a balela da passividade e a tolerância dos homens escravos que precederam o 13 de Maio (SenZALA, ano I, n.1, São Paulo, jan.1946, p.29).

Vale a pena observar que se, por um lado, a valorização da suposta superioridade do negro em relação ao branco no futebol era uma das preocupações da Imprensa Negra, por outro lado, quatro anos após a publicação dessa matéria, com a derrota do Brasil para o Uruguai na Copa de 1950, uma das justificativas da derrota, segundo indica a historiografia sobre o futebol brasileiro (SouTO, 2002), recaiu justamente sobre a constituição étnica dos jogadores negros, sobretudo Barbosa, o goleiro daquela seleção que teria falhado no segundo gol do Uruguai? 
Retornando à matéria, podemos observar que, além de apresentar um levantamento da raça/cor dos jogadores que estavam se preparando para disputar a Copa de 1950 pelo Brasil, ela reverbera o valor democrático do

\section{Considerações finais}

De acordo com Domingues (2009) a leitura desses jornais denuncia os problemas que atingiam a população negra no pós-abolição. Foram esses jornais que fizeram as primeiras denuncias públicas do "preconceito de cor" que grassava em várias cidades do país no início da República, impedindo os negros de frequentar determinados espaços justamente num contexto que corria a ideia que o Brasil, diferentes de outras naçôes, soubera superar o preconceito étnico-racial.

$\mathrm{Na}$ medida em que valorizavam o negro e sua incessante busca de elevação cultural e social, os jornais da imprensa negra contribuíram para que esse segmento que representa esse grupo étnicoracial adquirisse consciência racial e passasse a lutar pelos seus direitos de cidadão (DOMINGUES, 2009). Em relação ao futebol, podemos observar esses periódicos assumiram uma postura ambivalente ao noticiar as vitórias dos negros no esporte.

Verificamos, com base naqueles periódicos inclinados à causa negra, denúncias de preconceito, debates sobre a mestiçagem e a democracia racial, além da penetração do negro no espaço elitista do esporte. $\mathrm{Na}$ quele período, o Brasil vivia a construção da brasilidade, tendo como pano de fundo a ideologia nacional que pregava a relação positiva entre pretos e brancos na cultura brasileira, reproduzida através do futebol. A partir desse cenário, podemos observar que o sentimento da consciência racial, a necessidade de se integrar à nação e o desejo de ascensão social eram os motivos que mantinham unidos os negros através daquelas associações que promoviam o esporte, basicamente o futebol.

O futebol, que estava sendo investido de poder simbólico para representar o Brasil, estava também sendo apropriado e promovido pela Imprensa Negra junto aos seus pares, pois ela reconhecia que aquele era um campo no qual os negros se destacavam. Em congruência com essa demanda nacional, a Imprensa Negra passou a dar visibilidade às representações sobre o "corpo negro" na medida em que eram utilizadas para a construção da identidade nacional e contribuíam para valorizar o negro num esporte até então elitista, que se tornava um meio de ascensão social conforme o futebol se profissionalizava. esporte que, de alguma maneira, equiparava as "raças". Nesse cenário igualitário os negros sobressaíam, sendo reconhecidos como um grupo étnico/racial especialmente dotado para as atividades atlético-esportivas.
DOMINGUes (2009) disse que a imprensa negra foi pioneira na tarefa de propor alternativas concretas para superação do racismo na sociedade brasileira. Como o sucesso do negro no campo do esporte poderia coadunar para esse processo? A leitura que podemos fazer é que tais periódicos procuraram construir uma representação identitária do negro que privilegiasse o capital futebolístico, sem se esquecer dos predicados morais como a disciplina, a higiene e a ordem.

O bom desempenho no futebol, não só técnica, mas também disciplinarmente, seria o capital acionado pela Imprensa Negra para facilitar o acesso dos negros ao campo do futebol. Consciente de que esses valores eram marcas necessárias para a ascensão social de um negro no Brasil, a imprensa encontrou no futebol uma ferramenta que servia para denunciar e combater o preconceito que ainda resistia contra o negro no campo do esporte. A estratégia de divulgação dos feitos de sucesso dos negros no campo esportivo promovia uma identidade positiva do negro no futebol, em conformidade com as demandas daquele contexto: uma nação higienizada e disciplinada na esteira do projeto nacional que via no futebol um meio de expressão positiva da brasilidade.

Naquela sociedade pós-escravocrata, a Imprensa Negra representava um dos poucos espaços que permitiam aos seus pares construir uma nova identidade. Nesse sentido, é importante ressaltar a inclinação desse periódico para contestar os estereótipos negativos, mas sem se esquecer de exaltar os positivos. Pensar a positividade da raça era potencializar o capital dos negros para espaços estratégicos, no caso específico, para o futebol.

As páginas da Imprensa Negra reverberavam as representações dos negros para o futebol, que, nos dias atuais, são interpretadas como se estivessem vinculadas a expressões naturais e inatas exclusivas dos negros, como "irracionalidade, impulsividade, excesso, musicalidade, ginga, arte, malícia” (GoRDON JUNIOR, 1996, p.77). Essa representação é uma convicção nativa e é reiterada várias vezes na própria dinâmica da sociedade brasileira, especialmente por 
periódicos que, apesar da distância temporal, ocupam nos dias de hoje o mesmo papel da Imprensa Negra no início do século XX. Talvez o veículo de comunicação contemporâneo que mais se aproxima dos periódicos inclinados com a causa negra seja a revista Raça Brasil.

SCHWARCZ (2003, p.236) analisou o texto de abertura desta que seria a "revista dos negros brasileiros" e observou que, em seu primeiro número, ainda que não tenha nenhuma ligação com os primeiros periódicos, a revista continua reforçando os estereótipos "positivos" sobre os negros, ao se autodefinir como "a cara da nossa raça: "black", colorida, com balanço e ginga, bem brasileiros", ou declarar que "ser negro é ser alegre por natureza” (SCHWARCZ, 2003, p.236).

Como esse periódico, ao longo de suas 150 ediçôes têm dialogado com as representaçōes sobre a "raça negra" no espaço do futebol é algo que não sabemos. Surge aqui uma possibilidade de trabalho comparativo entre os periódicos das primeiras décadas do século XX eXXI, que, embora não tenham nenhuma ligação temporal, convergem no sentido de serem comprometidos com a construção positiva da identidade negra. Esta é uma sugestão para estudos futuros.

\section{Notas}

1. Os membros desses centros chamavam a si próprios de "homens de cor" ou "homens pretos", e seu coletivo de "classe".

2. Eram os jogos "Pretos x Brancos". Ver Abrahão (2010).

3. A palavra "estereótipo" - "pictures in our head" -, usada por Lippmann, quer indicar precisamente essas ideias e imagens que temos em mente e que constituem a parte subinteligente de nossas opiniōes e julgamentos sobre pessoas ou coisas. Desse modo, quando aqui falamos de estereótipos, queremos nos referir a essas imagens, explicaçôes, ideias ou sistemas de ideias que, generalizando o resultado de experiências parciais e limitadas, caracterizam o conteúdo alógico de nossos pensamentos, julgamentos e ações, imagens e explicações que tendem a se fixar e permanecer, resistindo à revisão crítica e racional. Os estereótipos são integrados ao sistema de valores do grupo e às pautas de conduta individuais de seus membros diante de situações de conflito social, antagonismos ou tensões intergrupais. "No nosso tempo", diz o professor Kimball Young - "os estereótipos refletem principalmente diferenças de classe, relaçôes de raças e conflitos religiosos e internacionais" (citado por Costa Pinto, 1953, p.186). Além disso, é de fundamental importância compreender que "um estereótipo nunca é neutro”, como diz Lippmann; ele é forjado e está sempre refletindo situações de conflito social, recorda Kimball Young (citado por Costa PinTo,, 1953, p.187). Somente encarando-o dentro dessa perspectiva é possível compreender a função que os estereótipos assumem na dinâmica social.

4. O negro, por exemplo, pertence a uma das etnias da raça humana.

5. A respeito das especificidades de cada um dos jornais, ver ANDREws (1998).

6. Chartier (1990) explica ainda que as percepções do real não são discursos neutros: "produzem estratégias e práticas que tendem impor à custa de outros por ela menosprezados, a legitimar um projeto reformador ou a justificar, para os próprios indivíduos, as suas escolhas e condutas. Por isso esta investigação sobre as representações supõe-nas como estando sempre colocadas num campo de concorrências e de competições cujos desafios se enunciam em termos de poder e de dominação" (p.17).

7. No Brasil, a história do futebol divide-se em quatro períodos amplos: 1894-1904, quando o futebol se manteve restrito aos clubes urbanos pertencentes a estrangeiros; 1905-1933, fase amadora, marcada por grandes passos de divulgação e pressão crescente para melhorar o nível do jogo, através de subsídios para os jogadores; 1933-1950, período inicial da profissionalização; e após 1950, fase de reconhecimento internacional, acompanhado pela comercialização sofisticada e pela maturidade como recurso nacional incontestável (Levine, 1982).

8. A profissionalização do futebol foi oficializada em 1933.

9. Essa derrota, segundo Mário Filho, "em vez de glorificar um novo ídolo do futebol brasileiro, que segundo todas as probabilidades seria outro mulato ou preto, à imagem e semelhança de Arthur Friedenreich e Leônidas da Silva, o que fez foi reavivar um racismo ainda não de todo extinto" (RoDRIGUES FilHo, 2003, p.280).

74 • Rev. bras. Educ. Fís. Esporte, São Paulo, v.26, n.1, p.63-76, jan./mar. 2012 


\section{Abstract}

The Black Press and the soccer in São Paulo in the beginning of the 20th century

In the first half of the 20th century, in São Paulo, there were associations dedicated to promote cultural and sport activities for the African American people. They emerged to denounce discriminatory practices and to promote ethnic sociability through athletics, boxing and, especially, soccer. One of them was the Black Press. In this article, the authors sought to understand the strategies of the Black Press to report the participation of black people in the emerging field of soccer. The contents of the Black Press, available in the National Library in the form of microfilms, were analyzed using the theoretical perspective of the Cultural History. The objective was to observe the continuity and regularity of the speech, the points of confrontation and symbolic dispute around the negotiation of the identity construction of "black" in the sport and identify, by means of the messages sent by those media outlets, the strategies of distinction used by the ethnic / racial group around the defense against negative representations or construction of positive representations of blacks in the emerging field of soccer. They concluded that the feeling of the racial consciousness, the need to integrate themselves with the nation and the desire for social mobility were the reasons that held the African Americans together through those associations. Thence, the "Black Press" tried to build a representation of black identity that emphasized the soccer resources, without forgetting moral matters as discipline, hygiene and order. The dissemination of the achievements of blacks in sports promoted a positive identity of black man in soccer, in accordance with the demands of that context: a sanitized and disciplined nation in accordance with the national project that understood soccer as a mean of positive expression of "Brazilianness".

UnITERMs: Black Press; São Paulo; Soccer.

\section{Referências}

A. A. S. Geraldo. O Clarim da Alvorada, 25 jan. 1930. p.2.

ABRAHÃO, B.O.L. O “preconceito de marca” e a ambiguidade do "racismo à brasileira” no futebol. 2010. Tese

(Doutorado) - Universidade Gama Filho, Rio de Janeiro, 2010.

ANDREWS, G.R. Negros e brancos em São Paulo (1888-1988). Bauru: EDUSC, 1998.

A VOZ DA RAÇA, São Paulo, 19 abr. 1933. p.4.

. São Paulo, abr. 1937. Página Esportiva, p.2.

BARTH, F. Grupos étnicos e suas fronteiras. In: POUTIGNAT, P.; STREIFF-FENART, J. Teorias da etnicidade. São Paulo: Fundação Editora da UNESP, 1998.

BASTIDE, R. Estudos afro-brasileiros. São Paulo: Perspectiva, 1973.

BOURDIEU, P. O poder simbólico. Lisboa: Difel, 1989.

CAMPEÃO do Centenário. O Progresso, São Paulo, 28 jul. 1929. Esporte, p.5.

CAMPEÃO do Centenário 1922. O Auriverde, São Paulo, 15 abr. 1928. p.5.

CHARTIER, R. A história cultural: entre práticas e representaçôes. Rio de Janeiro: Bertrand Brasil, 1990.

CLUBE A. Brasil. O Progresso, São Paulo, 28 jul. 1929. p.3.

COSTA PINTO, L.A. O negro no Rio de Janeiro: relações de raça numa sociedade em mudança. 2. ed. Rio de Janeiro: UFRJ, 1998.

D’ADESKY, J. Pluralismo étnico e multiculturalismo: racismo e anti-racismo no Brasil. Rio de Janeiro: Pallas, 2005.

DAMATTA, R. Carnavais, malandros e heróis: para uma sociologia do dilema brasileiro. 5. ed. Rio de Janeiro, Guanabara, 1990.

DAMO, A.S. Do dom à profissão: a formação de futebolistas no Brasil e na França. São Paulo: Hucitec, 2007.

DOMINGUES, P. Consciência de cor. In: FIGUEIREDO, L. (Org.). A era da escravidão. Rio de Janeiro: Sabin, 2009.

(Coleção Revista de História de Bolso).

ELIAS, N.; SCOTSON, J.L. Os estabelecidos e os outsiders. Rio de Janeiro: Jorge Zahar, 2000.

GENTES e fatos de outras épocas: S. Geraldo Vs. Flor de Belém. A Voz da Raça, São Paulo, 28 abr. 1934. s.p. 
GIACOMINI, S.M. A alma da festa: família, etnicidade e projetos num clube social da Zona Norte do Rio de Janeiro - o Renascença Clube. Belo Horizonte: UFMG, 2006.

GORDON JUNIOR, C. "Eu já fui preto e sei o que é isso" - história social dos negros no futebol brasileiro: segundo tempo". Pesquisa de Campo, Rio de Janeiro, n.3/4, p.65-78, 1996.

LAPIERRE, J.W. Le pouvoir politique et les langues. Paris: PUF, 1988.

LEVINE, R.M. Esporte e sociedade: o caso do futebol brasileiro. In: MEIHY, J.C.S. (Org.). Futebol e cultura: coletânea de estudos. São Paulo: Imprensa Oficial do Estado, 1982.

MAZZONI, T. História do futebol brasileiro. São Paulo: Olimpicus, 1950.

NOGUEIRA, O. Preconceito de marca: as relaçôes raciais em Itapetininga. São Paulo: Universidade de São Paulo, 1998. O PROGRESSO, São Paulo, 26 set. 1929. p.7.

O SÃO Geraldo é um clube que honra a colletividade negra no futebol paulista. O Clarim da Alvorada, São Paulo, 26 jul. 1931. p.3.

PARA orgulho dos pretos. O Progresso, São Paulo, 15 fev. 1930. p.5.

PENA, S.D.J. ; BIRCHAL, T.S. A inexistência biológica vesus a existênia social de raças humanas: pode a ciência instruir o etos social. Revista USP, São Paulo, n.68, p.10-21, 2005/2006.

PIRES, A.L.C.S. Associações de homens de cor: imprensa negra, movimentos negros e ideologias sociais (1915-1937). In: SALGUEIRO, M.A.A. (Org.). A república e a questão do negro no Brasil. Rio de Janeiro: Museu da República, 2005. POUTIGNAT, P.; STREIFF-FENART, J. Teorias da etnicidade. São Paulo: Fundação Editora da UNESP, 1998.

RODRIGUES FILHO, M. O negro no futebol brasileiro. 4. ed. Rio de Janeiro: Mauad, 2003.

ROSENFELD, A. Negro, macumba e futebol. São Paulo: EDUSP, 1993.

SÃO Geraldo X Brasil. O Auriverde, São Paulo, 29 abr. 1928. p.3.

SCHWARCZ, L.M. O espetáculo das raças. São Paulo: Companhia das Letras, 2002.

Racismo no Brasil. São Paulo: Companhia das Letras, 2003.

Retrato em branco e preto: jornais, escravos e cidadãos em São Paulo no final do século XIX. São Paulo: Companhia das Letras, 2001.

SENZALA, São Paulo, ano I, n.1, jan.1946. p.29.

SOUTO, S.M. Imprensa e memória da Copa de 50: a glória e a tragédia de Barbosa. 2002. Dissertação (Mestrado) Universidade Federal Fluminense, Niterói, 2002.

STORTI, V.; FONTENELlE, A. A história do Campeonato Paulista (1902-1996). São Paulo: Publifolha, 1997.

TUDO Preto . O Progresso, São Paulo, fev. 1931. p.4.

\begin{tabular}{r|l} 
ENDEREÇO & \\
Antonio J orge Gonçalves Soares & \\
R. Alzira Cortes, 5 - apto. 106 - Botafogo & Recebido para publicação: 27/05/2011 \\
22260-050 - Rio de Janeiro - RJ - BRASIL & Revisado: 31/ 10/2011 \\
e-mail: ajgsoares@gmail.com & Aceito: 23/01/2012
\end{tabular}

76 • Rev. bras. Educ. Fís. Esporte, São Paulo, v.26, n.1, p.63-76, jan./mar. 2012 